\title{
Domain Dimension of Family Relationships in the South of Johor through the Family Well-Being Index 2017
}

\author{
Siti Sarawati Johar \\ Institute for Social Transformation and Regional Development, \\ Universiti Tun Hussein Onn Malaysia, \\ 86400 Parit Raja, Batu Pahat, Johor, Malaysia; sarawati@uthm.edu.my
}

\section{ARTICLE INFO}

\section{Publication Info:}

Research Article

How to cite:

Johar, S. S. (2019). Domain

Dimension of Family

Relationships in the South of Johor through the Family Well-Being Index 2017. Society, 7(2), 185194.

DOI : 10.33019/society.v7i2.129

Copyright (C) 2019. Owned by Author(s), published by Society

\section{OPEN $\bigcirc$ ACcess CC) (i) (-)}

This is an open access article.

\author{
License: Attribution- \\ NonCommercial-ShareAlike \\ (CC BY-NC-SA)
}

\begin{abstract}
Family institutions are fundamental units of social importance in the process of human development, construction, and development, through the capacity of human capital formation. Physical development alone is meaningless if it is not accompanied by human development based on its natural nature. It is impossible to deal with internal conflicts and to challenge current family institutions because families cannot handle progressive social and economic development processes with simplicity and balance in the family. For example, when there is a disruption in family interaction, there is a loss of family relationships and non-compliance with the value system. Therefore, efforts to balance the demands of social and economic development must be consistent with strengthening relationships within family institutions, as emphasized in the Family Well-Being Index through the Family Relationships dimension. This effort is in line with the desire to create prosperity in family institutions which involves developing individuals and families in a balanced and holistic manner physically, spiritually, economically, socially and mentally. In line with that, a study aimed at testing the Family Well-Being Index was conducted on 319 respondents representing their families in the Pasir Gudang district, Johor Bahru, Malaysia, in 2017. For discussions in this study, the focus would be on the family relationships dimension in terms of Motivational Support, Togetherness, and Curiosity. Overall study findings indicate that the Family Well-Being Index for the Family Relationships dimension is at an excellent level, thus providing relevant interpretations of positive perceptions and practices among study respondents, through testing the Family Relationships domain in three main dimensions.
\end{abstract}


Received: November 25, 2019;

Accepted: December 27, 2019;

Published: December 31, 2019;

\section{Keywords: Dimension; Domain; Family Relationships; Index; Well-Being}

\section{Introduction}

The family is a very dynamic social institution and an important element in helping to produce a holistic generation. The function of family relationships is a key element in strengthening families to live more prosperous and happy (Hassan, 2013). Having a happy family is a dream for every human being as long as it can affect the emotional, physical, and behavioral aspects. Parents-led family institutions are key agents that serve as significant variables in the process of developing educational styles, communication, interaction and child attends and the continuing commitment of parents to children. As emphasized in the theory of Abraham Maslow, it is argued that before humanity reaches a higher level of life, which is a hallmark of success, the fact that humans need love. Clearly, the love that children want to have comes from the sincere interaction and focus of both parents and siblings. Because of that love and affection, a child's soul will have the power to continue to breathe in the more meaningful days of life. This section will further describe the criteria in the Family Relationships dimension index as a complement to the Family Well-Being Index.

\section{Literature Review}

\section{A. The Style of Parenting}

Among the criteria closely related to the dimension of Family Relationships is the style of parenting or also referred to as the style of parenting among parents towards their family. This criteria has a significant relations with the causes and effects of family relationships scenarios. Style refers to the way parents educate their children about strengthening and punishment, to develop personalities that are appropriate to the situation (Hassan, 2013). There are several main parenting styles mentioned by Baumrind (1991) in Baharudin \& Ibrahim (2008), which are authoritative, authoritarian, and permissive.

\section{1) Authoritative Style}

Authoritative style is the interaction between mother, father and child, which only focuses on children in various aspects of needs. This style of parenting shows that parents are always confident, kind, responsive, and accept and make decisions based on reasonable reasons. This method is more likely to provide support than provide punishment (Hassan, 2013). Therefore, it is common for children as a result of this parenting style to develop into a personal child that is in line with community and family norms. Children will also become more confident, brave, independent and able to achieve stronger emotional development processes, along with positive social systems.

\section{2) Authoritarian Style}

This parenting style is traditional because it shows parents have full control over their children. Therefore, children cannot defy and must obey what their parents have set. The family situation becomes more rigid, tighter, very structured, and physically punishable by mistake. As a result, children will become stubborn, depressed, rebellious in silence, and low selfconcept (Baharudin \& Ibrahim 2008). 


\section{3) Permissive Style}

This kind of parenting also has a very high tolerance for children, which causes children to freely do anything they want without parental control. Parents only obey whatever their children are asked for without confrontation. As a result, children become mischievous, unresponsive, irresponsible, weak in control, immature, and fail to set real-life goals. Children as a result of this parenting style are also very vulnerable to behavioral deficiency and tend to violate the rules (Baharudin \& Ibrahim 2008).

\section{B. Parent Involvement in Children's Life}

This depends on the aspect of parental skills in understanding and caring for children. Children with high levels of adherence to parents were found to have an external locus of control. These children believe that external forces are behavioral determinants and underlie their adherence to authority (Yusof et al., 2002). Excessive parental care does not actually help make children better, but it makes children uncomfortable in the long run. The role of parental support and involvement in children's affairs and needs greatly influences their lives.

Therefore, parents need to have skills in managing their own involvement in the daily lives of children, such as knowledge of children's activities, always open to discussion, ready to help, and getting to know their children's friends. Parental involvement that is relevant to the situation can be an intimate entity that positively influences children's emotional, mental, and behavioral development.

The ability of parents to be involved in the lives of children is also described as the ability of parents to use a focused and interesting educational method by paying attention to children's problems more seriously and wisely. In fact, it may be reasonable for children to achieve longterm family well-being.

\section{Family Resilience}

This criteria is in the domain of childcare ability to foster strength that allows families to endure the problems of life. Creating positive self-esteem in children as a result of dynamic care and education is one way to achieve endurance. This dimension is closely related to parents' ability to provide motivation and positive support for children.

In addition, parents who can provide a strong source of encouragement to children can help elevate children's self-concept more positively. Mutual relationships, meetings, and prosperity between parents and children will build an appropriate appreciation for self-sufficiency in children (Bulanda \& Majumdar, 2009). The influence of parents is very strong in establishing children's self-esteem through involvement and quality of relationships. As a result, parents and children can become more resilient family members in solving various problems, while also being more united in the pursuit of mutual success and happiness.

\section{Family Function}

Family functions are functions related to psychological adjustment and involve an explanation of rules, standards of behavior, control and appropriate methods for handling family problems (Hassan, 2013). Unity and flexibility are elements that make the family work. Family cohesion is a bond of feelings and emotions between family members, while adaptability refers to the ability of the family to change the structure of power, role relationships, and relationships between members according to the family circumstances (Nasir \& Omar, 2006). 


\section{Domain Dimension of Family Relationships in the South of Johor through the Family Well-Being Index 2017}

Family functions include how family members communicate, relate, and maintain relationships with one another, and work together to solve problems. Healthy communication among family members also affects family functions, while also being able to strengthen relationships. To be clear, the strength of family functioning is also the result of good interaction through understanding, emotional connection and effective communication (Bailey, 2009).

\section{E. Togetherness}

This domain focuses on the time that parents need for themselves and the time they have to spend with family members. Involving in the family, such as spending time together and trying to avoid family conflict is one of the key factors in family function (Hassan, 2013). The influence of parents is very strong in establishing the true family meaning because it is important for the personalities of children while spending time together in every family activity. Family involvement is the main factor of a family function. Quality time spent, such as family activities, parenting and parental efforts to balance work time with family can have a positive effect on family relationships (Hornberger et al., 2009). With parents' efforts to develop children's good behavior, give each other strength, to respect each other, and interact well in any problem, the family relationships will be closer.

\section{Research Methodology}

This study uses a mixed methodology that is quantitative and qualitative. Quantitative methods through surveys using questionnaires were conducted to collect data. This study also cross-sectional study.

The use of qualitative methods is through a roundtable approach conducted by inviting a panel of experts to gain critical thinking to strengthen the role of the Darul-Ta'zim Family Development Foundation (Yayasan Pengembangan Keluarga Darul-Ta'zim or YPKDT) as an organization that serves To create a prosperous family and strengthen the insights gained through surveys. The panel consists of the National Population and Family Development (Lembaga Penduduk dan Pembangunan Keluarga Negara or LPPKN) officers, representatives of Non-Governmental Organizations (NGOs), representatives of the Single Mother Union, and YPKDT activists.

As for sampling, a total of 319 samples with different backgrounds was selected for this study. The selected respondents also consisted of respondents who had participated in the program or who had never participated in the YPKDT program. Respondents were also divided into those who lived in urban and rural areas.

Quantitative data were then analyzed using SPSS software version 22.0. Qualitative data were analyzed using Pareto Analysis.

\section{Results and Discussion}

\section{A. Domain Dimension Indicator of Family Relationships}

In daily life, the family relationships form is one of the key elements in achieving the wellbeing and happiness of the family (Hassan, 2013). According to the Minister for Women, Family and Community Development, Dato 'Sri Rohani Abdul Karim (Kementerian Pembangunan Wanita, Keluarga dan Masyarakat Malaysia, 2017), producing a Family Well-Being Index every three to five years, needs to be implemented, so that it can be used as a guide and important input for policy makers, planners and program managers to evaluate the extent of the wellbeing level of family life in Malaysia. Go further, to help them develop more effective strategies and programs that fit their goals. This is a proactive step that can be implemented by LPPKN to 


\section{Domain Dimension of Family Relationships in the South of Johor through the Family Well-Being Index 2017}

continuously monitor the well-being of Malaysian families. In line with this statement, this study was also conducted as a measurement effort on the family relationships domain indicator of the Family Well-Being Index in Malaysia. The discussion will be based on the analysis that has been done.

\section{1) Family Relationships Domain (Overall)}

The findings from the table below show the index scores for the entire dimension domain in family relationships. From the average rate table for the entire domain of the Family Relationships dimension, it was found that 237 respondents were in excellent condition with a total percentage of $74.3 \%$, compared with a value of $21.6 \%$ for a good level with a total of 69 people. The amount is far different from the value of $3.8 \%$ and $0.3 \%$, respectively at the level of weak and moderate with a total of 13 respondents.

The average score for all domains of this dimension was 8.47 from a maximum scale of 10, and it was found that the level for all domains of this dimension was at an excellent level. Thus, it clearly shows that excellent numbers are dominant in the results of this study, but it can also indicate that the Family Relationships indicators in the Family Well-Being Index provide relevant interpretations of positive perception and practice in the family relationships domain through three main dimensions.

Table 1

Score of Average Level of Family Relationships Domain

\begin{tabular}{lrr}
\hline Level & Frequency & Percentage (\%) \\
\hline Weak & 1 & 0.3 \\
Moderate & 12 & 3.8 \\
Good & 69 & 21.6 \\
Excellent & 237 & 74.3 \\
\hline
\end{tabular}

Source: (Primary Data, 2017)

\section{2) Family Relationships Domain (Motivational Support)}

The results of these study analyses based on questions numbers 24, 25, 26, 28, and 29, it was found that the domain level of motivational support is at an excellent level. The average score value indicates the maximum average is 8.83 , while the minimum is 8.31 . The average score value indicates the maximum average is 8.83 , while the minimum is 8.31 . This figure indicates that the family relationships score for the parent motivational support domain for children in the family is 8.55 from a maximum of 10. Based on the above analysis, the majority of respondents agreed that there were indeed discussion activities with their families. Respondents also agreed that they trained their family members to become self-reliant in their daily lives to better understand their responsibilities and to understand each other's functions and responsibilities for the well-being of the family.

Respondents agreed that they felt more at ease when they were with family members. In total, the scores in the motivational support domain are at a high level, and excellent. This clearly shows that the Family Relationships Index in the motivational support domain has been practiced among the heads of the family such as father or mother. These practices clearly show that the head of the family strives to provide motivational support, and encouragement towards

Copyright ( 2019. Owned by Author(s), published by Society. This is an open access article under CC-BY-NC-SA license. 
the shaping of Family Relationships, which is predominantly positive. This finding also shows that the high and excellent scores obtained, are in line with the high scores obtained in the Family Relationships domain in the Malaysian Family Well-Being Index Study conducted by the National Population and Family Development (Lembaga Penduduk dan Pembangunan Keluarga Negara or LPPKN) (2016) as a cross-sectional study to examine the level of family well-being.

Table 2

Average Score by Family Relationships Domain (Motivational Support)

\begin{tabular}{llll}
\hline Number & Description & Average & Level \\
\hline 24. & I talked to my family if there was a problem. & 8.31 & Excellent \\
25. & I train my family members to be self-reliant. & 8.34 & Excellent \\
26. & I felt calm with my family members. & 8.82 & Excellent \\
28. & The decision I made was the result of a discussion with my & 8.44 & Excellent \\
& family members. & & \\
29. & I give praise when family members do good things. & 8.83 & Excellent \\
& $\begin{array}{l}\text { Average Score by Family Relationships Domain } \\
\text { (Motivational Support) }\end{array}$ & 8.55 & Excellent \\
\hline
\end{tabular}

Source: (Primary Data, 2017)

\section{3) Family Relationships Domain (Togetherness)}

Based on questions from numbers 27 and 33, it was found that the domain level of togetherness is at an excellent level. Total shows the average family relation score for domain togetherness by parents with children in the family is 8.31 from a maximum of 10 . The analysis below is a test for domain togetherness. The findings show that the majority of respondents agreed with the practice of eating together with their family members. In addition, they also agreed that they could balance work time with family time. The high level of results obtained in this domain can give the impression that family well-being still exists in the Malaysian community, despite the current challenges. That time needs to be organized and arranged by the head of the family and accepted together to create a better interaction with family members. It can also prevent children from being trapped with various problems, and the delinquent behavior that gives a negative impression to all (Zakaria et al., 2016).

Table 3

Average Score by Family Relationships Domain (Togetherness)

\begin{tabular}{llll}
\hline Number & Description & Average & Level \\
\hline 27. & I ate together with my family members. & 8.62 & Excellent \\
33. & I can balance between work time and time with family. & 8.00 & Excellent \\
& $\begin{array}{l}\text { Average Score by Family Relationships Domain } \\
\text { (Togetherness) }\end{array}$ & 8.31 & Excellent \\
\hline
\end{tabular}

Source: (Primary Data, 2017)

Copyright (C 2019. Owned by Author(s), published by Society. This is an open access article under CC-BY-NC-SA license. 


\section{4) Family Relationships Domain (Curiosity)}

Based on questions from numbers 30 to 32, it was found that the domain level of curiosity is at an excellent level. The average score indicates the maximum average is 8.51, while the minimum average is 8.17. This figure shows the average Family Relationships score for the curiosity domain by parents of children in the family is 8.33 from a maximum scale of 10 .

Analysis that examines the domain of curiosity as shown below shows that the majority of respondents agreed on the existence of anxiety practices for their family members. The head of the family can convey their anxiety and curiosity by asking members of their family with who they are if they are outside the house. It seems that the head of the family does not hesitate to interfere in such matters with family members, but such practices are the responsibility of the head of the family and must be accepted rationally by their family members on the basis of goodness, and mutual prosperity. They also agreed that they knew their family friends. They also agreed with the statement about the practice of curiosity about the daily activities of their family members. The need for curiosity is important, because in the family there should be many things to be shared together so that anxiety and suspicion do not arise. High-level and excellent results for this domain can provide a strong picture of family relationships, and the responsibilities of the head of the family are still dominant among the people in Malaysia. The domain is also a subjective perception among respondents that is closely related to respondents' past realistic experiences, and involves methods related to the elements of quality of life through the well-being of family relationships (Noor, 2014).

Table 4

Average Score by Family Relationships Domain (Curiosity)

\begin{tabular}{llll}
\hline Number & Description & Average & Level \\
\hline 30. & I asked family members with whom they came out. & 8.51 & Excellent \\
31. & I recognize my family friends. & 8.31 & Excellent \\
32. & I know the daily activities of my family. & 8.17 & Excellent \\
& Average Score by Family Relationships Domain & 8.31 & Excellent \\
& (Curiosity) & & \\
\hline
\end{tabular}

Source: (Primary Data, 2017)

\section{B. Recommendations for the Family Relationships Domain}

There are a number of recommendations that can be implemented by government agencies or Non-Governmental Organizations (NGOs) to help family institutions reach the Family WellBeing Index, which is balanced and integrated, thus helping to create a dominant effective and the quality family institution

\section{1) Organize a Parenting Course Regularly but Permanently}

The aim is to be a guide and guidance for parents, in leading the family life, which is more directed and more meaningful. In fact, this program can help to increase the role of parents as the best role models for children, so that parents realize that they must be on the right track as parents with positive and relevant parenting styles to the needs of children. This course is also 
important for young parents because it is very important for them to learn and understand the techniques and methods that are appropriate in building a prosperous family.

\section{2) Conducting Personality Tests among Parents}

The aim is to help parents recognize their personalities, and their true potential, in order to help them function as parents who are able to recognize and understand the souls and behaviors of their children. When parents become more aware of their own personality, they can try to adapt their personality in parenting towards their children who have various characters and souls. Thus, communication between parents and children will be more effective and meaningful through the interpretation of words and body language which is clearly understood, thereby avoiding misinterpretation or misunderstanding that can cause conflict.

\section{3) Encourage Parents to Attend Individual and Group Counseling}

The aim is to help parents solve family problems in the right way, such as being able to control their emotions, understand their own emotional changes and children's emotions. Even parents can express themselves in the right way to reduce stress when dealing with problems and family conflicts. Counseling sessions also help parents and children learn how to be honest with each other, to prevent them from continuing to have self-destructive feelings, or cause more problems due to loss of control. Likewise, family relationships become more intimate when communication becomes clearer and reaches deeper into their expectations and aspirations, while also understanding the importance of appreciating and being appreciated.

The findings of this study should be able to help the society and national experts, not to be tired of continuing to plan, design and implement programs to maintain family well-being, and to prevent the collapse of family institutions consistently. For dimension indicators in this family relationships, parents as the head of the family can continue to be assisted in attending parenting skills programs, especially involving verbal and non-verbal communication skills with children.

This skill is crucial in preventing conflicts that lead to instability, crisis, and family breakdown. Conflicts can occur only due to misinformation, misunderstanding, misinterpretation, negative thoughts and emotions, difficulty in being flexible in any circumstance. Even the practice of attitudes that are too dominating or too dominated is also not appropriate to be practiced in family life and other committed relationships, because the situation will only become more chronic when there are serious ethical violations against self, family, and community.

Therefore, the family institution should be developed with more knowledgeable and scientific elements, to continue the legacy of human resources which more affectionately, on foundations that align with universal values and moral values.

\section{Conclusions}

Family institutions are the leading socialization agents in creating new generations. Parents as heads of family institutions are very important agents of change, because they act as the main catalyst in the process of shaping children's lives, as a result of continuing a prosperous generation through dynamic family relationships. Significantly, parents need to play a more efficient role in ensuring that the self-concept and attitudes of children are on the right track, and fulfilling the demands of a value, religious and universal system, for the continuity of a more meaningful future, while at the same time bringing continuity to a generation that has good character, discipline, and has knowledge. 


\section{Domain Dimension of Family Relationships in the South of Johor through the Family Well-Being Index 2017}

The positive elements of the child's human development are also closely related to the shaping of self-concept in them. The development of the self-concept of children positively is very closely related to the function and character of parents in family institutions, because it is clear that it is the most dominant institution towards children from birth until they become part of the community.

The shaping of self-concept, which is normal and stable, is the result of healthy parenting, which leads to the preservation of identity, 'I'm fine - you're fine'. These elements are the catalyst for creating prosperity in family relationships. The main factor is not only the body size and appearance style, but every gesture and speech of parents have a major influence on every inch of children's development and life in a long time.

Children are active observers, but they are also passive assessors. Children from early age actively observe the behavior of parents, family members, and members of the community, so that conditions are formed, which become 'mirrors' and 'models' that are embedded in their subconscious minds.

Thus, parents need to be more careful to guide and direct the children's attention and assessment, in order to align with the value system. In fact, parents are responsible for maintaining and ensuring the influence that surrounds the daily lives of their children and their entire families is an influence that can build the personality of family members more brilliantly, both directly and indirectly.

\section{Acknowledgement}

Special thanks to the Darul Ta'zim Family Development Foundation (Yayasan Pembangunan Keluarga Darul Ta'zim or YPKDT) for funding this study fully, so that this study was successfully completed. Thank you to the Committee of YPKDT and researchers from the Institute for Social Transformation and Regional Development, Universiti Tun Hussein Onn Malaysia, for their collaborative efforts to enable this study to be completed over a 4-month period from September to December 2017.

\section{References}

Baharudin, R., \& Ibrahim, R. (2008). Keluarga, Kanak-kanak dan Remaja. Serdang: Penerbit Universiti Putra Malaysia.

Bailey, S. J. (2009). Positive Family Communication. Retrieved 09 12, 2017, from http://msuextension.org/publications/HomeHealthandFamily/.

Bulanda, R. E., \& Majumdar, D. (2009). Perceived parent-child relations and adolescent selfesteem. Journal of Child and Family Studies, 18(2), 203-212.

Hassan, A. (2013). Kompilasi Kajian Kesejahteraan Psikologi. Batu Pahat: Penerbit Universiti Tun Hussein Onn Malaysia.

Hornberger, L. B., Zabriskie, R. B., \& Freeman, P. (2010). Contributions of family leisure to family functioning among single-parent families. Leisure Sciences, 32(2), 143-161.

Kementerian Pembangunan Wanita, Keluarga dan Masyarakat Malaysia. (2017). Indeks Kesejahteraan Keluarga Malaysia Berada di Tahap Sederhana. Laporan Indeks Kesejahteraan Keluarga Malaysia 2016 in Malaysian Global Innovation And Creativity Centre (MaGIC), Selangor, February 28, 2017. 
Lembaga Penduduk dan Pembangunan Keluarga Negara. (2016). Laporan Indeks Kesejahteraan Keluarga. Kuala Lumpur: Lembaga Penduduk dan Pembangunan Keluarga Negara, Kementerian Pembangunan Wanita, Keluarga dan Masyarakat Malaysia.

Nasir, R., \& Omar, F. (2006). Kesejahteraan Manusia: Perspektif Psikologi. Bangi: Penerbit Universiti Kebangsaan Malaysia.

Noor, N. M. (2014). Pembentukan Indikator Kesejahteraan Keluarga Di Malaysia. In: Profesionalisme dalam Kaunseling dan Cabaran Masa Kini di Malaysia, pp. 319-360. Kuala Lumpur: Dewan Bahasa \& Pustaka.

Yusof, A. M., \& Amaji, N. M. (2002). Kepimpinan Ibu Bapa dan Kepatuhan kepada Autoriti dalam kalangan Remaja Melayu. Jurnal Psikologi dan Pembangunan Manusia, 18, 3-18.

Zakaria, P., Nobaya Ahmad, N., \& Md Noor, A. M. (2016). Perkaitan antara hubungan kekeluargaan dan tingkah laku delikuens remaja di Kuala Terengganu. In: International Conference on Youth (ICYOUTH) 2016, Seri Kembangan, Selangor, November 15-17, 2016.

\begin{abstract}
About the Author
Siti Sarawati Johar, is a Senior Lecturer in the Department of Social Sciences, Center for General Studies and Curriculum at Universiti Tun Hussein Onn Malaysia. The author is a Research Fellow at the Institute for Social Transformation and Regional Development, Universiti Tun Hussien Onn Malaysia and has 12 years of teaching and research experience at Universiti Tun Hussien Onn Malaysia. The author's research experience includes the areas of Educational Psychology, Organizational Psychology, Emotional Intelligence, Emotional WellBeing, and Human Development. The author has had many articles that are indexed and nonindexed related to Educational Psychology, Organizational Psychology, Humanities, Management and Human Resource Development. Her interests and skills are also in NeuroLinguistic Programming (NLP), as well as being an NLP practitioner.
\end{abstract}

